Check for updates

Cite this: Mater. Adv., 2021 2, 2730

Received 22nd February 2021, Accepted 16th March 2021

DOI: $10.1039 / \mathrm{d} 1 \mathrm{ma} 00159 \mathrm{k}$

rsc.li/materials-advances

\title{
Elucidating zinc-ion battery mechanisms in freestanding carbon electrode architectures decorated with nanocrystalline $\mathrm{ZnMn}_{2} \mathrm{O}_{4} \dagger$
}

\begin{abstract}
Megan B. Sassin, (D) *a Maya E. Helms, ${ }^{a}$ Joseph F. Parker, (D) a Christopher N. Chervin, (D) ${ }^{a}$ Ryan H. DeBlock, (D) a Jesse S. Ko, (D) $\ddagger^{b}$ Debra R. Rolison (D) ${ }^{a}$ and Jeffrey W. Long (D) ${ }^{a}$

Rechargeable zinc-ion batteries represent an emerging energy-storage technology that offers the advantages of low cost, use of abundant and nontoxic materials, and competitive energy content in lightly packaged forms. Nanoscale manganese oxides are among the most promising positive-electrode materials for zinc-ion cells, and their performance is further enhanced when these oxides are expressed as conformal deposits on porous carbon architectures, such as carbon nanfoam paper (CNF). We describe an "in-place" conversion of nanometric birnessite $\mathrm{Na}^{+}-\mathrm{MnOx}$ @CNF to crystalline spinel $\mathrm{ZnMn}_{2} \mathrm{O}_{4} \mathrm{QCNF}$, a manganese oxide polymorph that nominally contains sites for $\mathrm{Zn}^{2+}$ insertion. The $\mathrm{ZnMn}_{2} \mathrm{O}_{4} \mathrm{OCNF}$ cathodes are electrochemically conditioned in two-terminal cells and ex situ characterized using $\mathrm{X}$-ray diffraction, scanning electron microscopy, energy-dispersive spectroscopy, and $X$-ray photoelectron spectroscopy. Despite specific $\mathrm{Zn}^{2+}$ insertion sites in $\mathrm{ZnMn}_{2} \mathrm{O}_{4}$, we demonstrate that the predominant discharge mechanism involves coupled insertion of protons and precipitation of $\mathrm{Zn}_{4}(\mathrm{OH})_{6} \mathrm{SO}_{4} \cdot x \mathrm{H}_{2} \mathrm{O}$; upon recharge, protons deinsert and $\mathrm{Zn}_{4}(\mathrm{OH})_{6} \mathrm{SO}_{4}$ dissolves.
\end{abstract}

\section{Introduction}

Manganese oxides ( $\mathrm{MnO} x$ ) have a long history as charge-storing materials in devices ranging from primary alkaline $\mathrm{Zn} / \mathrm{MnO}_{2}$ cells $^{1}$ to rechargeable Li-ion batteries ${ }^{2}$ to aqueous-electrolyte electrochemical capacitors. ${ }^{3-6}$ Interest in these oxides is on the rise because of their prospective use as positive electrodes in rechargeable $\mathrm{Zn}$-ion cells versus a $\mathrm{Zn}$ metal negative electrode in $\mathrm{Zn}^{2+}$-based aqueous electrolytes. ${ }^{7-15}$ This cell chemistry inherits the advantages of the ubiquitous alkaline $\mathrm{Zn} / \mathrm{MnO}_{2}$ battery-low-cost, abundant components and the ability to deliver moderately high specific energy_but uses an even safer mild-pH electrolyte and is extensively rechargeable (hundreds of cycles). Other metal oxides, ${ }^{16-18}$ sulfides, ${ }^{19-21}$ and phosphates ${ }^{22-24}$ are also under investigation, but MnOx is the most likely to transition to commercial $\mathrm{Zn}$-ion batteries because of its lower cost and favorable redox potential (discharge voltage on the order of $1.3 \mathrm{~V}$ vs. $\left.\mathrm{Zn} / \mathrm{Zn}^{2+}\right)$.

\footnotetext{
${ }^{a}$ Code 6170, Surface Chemistry Branch, U.S. Naval Research Laboratory, Washington, DC, 20375, USA. E-mail: megan.sassin@nrl.navy.mil

${ }^{b}$ Former NRC Postdoctoral Associate at the U.S. Naval Research Laboratory, USA $\dagger$ Electronic supplementary information (ESI) available: Tables of composition and structural properties; data from additional XRD, EDS; XPS, impedance, microscopy, and voltammetric analyses. See DOI: 10.1039/d1ma00159k

‡ Present address: Applied Physics Laboratory, Baltimore, MD USA.
}

A key advancement toward rechargeable $\mathrm{Zn}$-ion batteries was the recognition that nanostructured forms of $\mathrm{MnOx}$ undergo reversible redox reactions when electrochemically cycled in mild-pH aqueous electrolytes that contain $\mathrm{Zn}^{2+}$ salts (e.g., $\mathrm{ZnSO}_{4}$ ). Early reports suggested that insertion/intercalation of $\mathrm{Zn}^{2+}$ into $\mathrm{MnO}$, coupled with $\mathrm{Mn}^{3+/ 4+}$ redox, ${ }^{16-18}$ provides reversible cycling to relatively high MnOx-specific capacity $\left(>200 \mathrm{~mA} \mathrm{~h} \mathrm{~g} \mathrm{~g}^{-1}\right)$. Other studies, however, show evidence for a multistep reaction with comparable specific capacity that involves proton insertion at MnOx; the coupled increase in local $\mathrm{pH}$ drives the precipitation of a hydrated $\mathrm{Zn}_{4}(\mathrm{OH})_{6} \mathrm{SO}_{4}$ at the electrode surface. ${ }^{25-33}$ This complex discharge reaction can often be reversed by re-oxidizing MnOx, resulting in the release of protons and at least partial dissolution of the $\mathrm{Zn}_{4}(\mathrm{OH})_{6} \mathrm{SO}_{4} \cdot x \mathrm{H}_{2} \mathrm{O}$ precipitate. In reality, both mechanisms may be operative for a given $\mathrm{MnO} x$ material, ${ }^{34}$ particularly those that are disordered, nanoscale, and/or porous. Optimizing the performance of MnOx-based positive electrodes for $\mathrm{Zn}$-ion batteries requires understanding the influences of MnOx polymorph and electrode structure on the charge-storage mechanism, which ultimately impacts rate capability, capacity, and cycle life. ${ }^{10}$

Recently, we explored the electrochemical $\mathrm{Zn}$-ion behavior of birnessite-like $\mathrm{Na}^{+}$-compensated manganese oxide $\left(\mathrm{Na}^{+}-\mathrm{MnO} x\right)$ distributed as ultrathin $(<20$ nm-thick $)$ coatings throughout porous carbon nanofoam papers (MnOx@CNF). ${ }^{35,36}$ These 
binder-free electrodes exhibit theoretical one-electron capacity (308 $\mathrm{mA} \mathrm{h} \mathrm{g}_{\mathrm{MnO} 2}{ }^{-1}$ ) at moderate rates (1C) in $1 \mathrm{M} \mathrm{ZnSO}_{4}{ }^{35}$ When $\mathrm{Na}_{2} \mathrm{SO}_{4}$ is added to the electrolyte, high rate (20C) operation is enabled by pseudocapacitance mechanisms. Ex situ characterization after conditioning at pertinent cell voltages confirms that $\mathrm{H}^{+}$insertion/de-insertion and subsequent $\mathrm{Zn}_{4}(\mathrm{OH})_{6} \mathrm{SO}_{4} \cdot x \mathrm{H}_{2} \mathrm{O}$ precipitation/dissolution is the dominant charge-storage mechanism for birnessite-like $\mathrm{Na}^{+}$MnOx@CNF. The reversibility of these complex multiphase reactions depend on electrolyte composition and the pore structure of the CNF-based architecture. ${ }^{36}$

Herein, we investigate $\mathrm{Zn}$-ion charge-storage mechanisms for another $\mathrm{MnOx}$ polymorph, spinel-type $\mathrm{ZnMn}_{2} \mathrm{O}_{4}$, which contains tetrahedral sites that nominally accommodate $\mathrm{Zn}^{2+}$ insertion for divalent charge storage. ${ }^{37-42}$ The disordered birnessite-like $\mathrm{Na}^{+}-\mathrm{MnO} x$ coatings on CNFs used in our previous study are readily converted to spinel $\mathrm{ZnMn}_{2} \mathrm{O}_{4}$ via topotactic ion-exchange $\left(\mathrm{Zn}^{2+}\right.$ for $\left.\mathrm{Na}^{+}\right)$, followed by mild thermal treatment. This transformation is achieved while maintaining the nanoscale, conformal nature of the as-deposited MnOx at the carbon surfaces and the through-connected pore structure of the CNF (Fig. S1, ESI $\dagger$ ). We now have the opportunity to directly compare two distinct $\mathrm{MnO} x$ polymorphs (birnessite $v s$. spinel $\mathrm{ZnMn}_{2} \mathrm{O}_{4}$ ), but expressed in identical multifunctional electrode architectures.

We first examine key electrochemical properties of $\mathrm{ZnMn}_{2} \mathrm{O}_{4} @ \mathrm{CNFs}$ in two-terminal cells with an aqueous $\mathrm{Zn}$ ion electrolyte using cyclic voltammetry, AC electrochemical impedance, and galvanostatic charge-discharge for long-term cycling. Ex situ characterization via diffraction, microscopy, and spectroscopy of electrochemically conditioned $\mathrm{ZnMn}_{2}$ $\mathrm{O}_{4}$ @CNFs reveals that the dominant charge-storage mechanism is similar to that of $\mathrm{Na}^{+}-\mathrm{MnO}$ @CNF, despite the presence of specific $\mathrm{Zn}^{2+}$ insertion sites in nanocrystalline $\mathrm{ZnMn}_{2} \mathrm{O}_{4}$ spinel. The charge-storage mechanism involves $\mathrm{H}^{+}$-insertion/de-insertion and subsequent precipitation/dissolution of $\mathrm{Zn}_{4}(\mathrm{OH})_{6} \mathrm{SO}_{4} \cdot x \mathrm{H}_{2} \mathrm{O}$ at the electrified interfaces.

\section{Results and discussion}

We previously demonstrated crystal engineering of disordered birnessite $\mathrm{Na}^{+}-\mathrm{MnO}$ @ @CNF to crystalline spinel $\mathrm{LiMn}_{2} \mathrm{O}_{4} @$ $\mathrm{CNF}^{43-45}$ here we show that this approach can be generalized to produce the $\mathrm{Zn}^{2+}$-containing spinel analogue, $\mathrm{ZnMn}_{2} \mathrm{O}_{4}$ (a)CNF (Fig. 1a). The first step of the process involves electroless redox deposition from aqueous permanganate to generate nanoscale $\mathrm{Na}^{+}-\mathrm{MnO} x$ coatings on the carbon surfaces throughout the CNF paper. ${ }^{46,47}$ The resulting $\mathrm{Na}^{+}$-MnOx@CNFs are soaked in $1 \mathrm{M} \mathrm{ZnSO}_{4}(\mathrm{aq})$ to exchange $\mathrm{Na}^{+}$in the lamellar $\mathrm{MnO} x$ domains with $\mathrm{Zn}^{2+}$, then copiously rinsed and dried to obtain birnessite-like $\mathrm{Zn}^{2+}$-MnOx@CNFs. The nanoscale nature of the oxide coating facilitates crystallization at a relatively mild temperature $\left(300{ }^{\circ} \mathrm{C}\right)$, which minimizes particle ripening of the MnOx coating (Fig. $1 \mathrm{~b}$ and $\mathrm{c}$ ), as previously observed with $\mathrm{LiMn}_{2} \mathrm{O}_{4} @ \mathrm{CNFs} .{ }^{43,44}$ The thermal processing step under
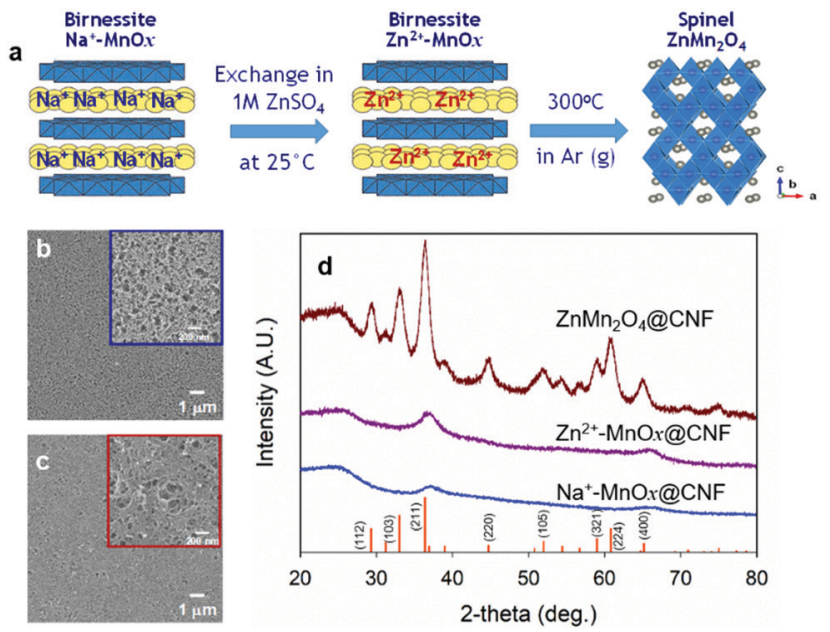

Fig. 1 (a) Schematic of in-place conversion from birnessite $\mathrm{Na}^{+}-\mathrm{MnO}$ to spinel $\mathrm{ZnMn}_{2} \mathrm{O}_{4}$; (b and c) Scanning electron micrographs at low and high magnification (inset) of (b) $\mathrm{Na}^{+}-\mathrm{MnOx}$ aCNF and (c) $\mathrm{ZnMn}_{2} \mathrm{O}_{4}$ aCNF; (d) X-ray diffraction patterns of $\mathrm{Na}^{+}-\mathrm{MnOx}\left(\mathrm{CNF}, \mathrm{Zn}^{2+}-\mathrm{MnOx} \mathrm{CCNF}\right.$, and $\mathrm{ZnMn}_{2} \mathrm{O}_{4} \mathrm{aCNF}$. The diffraction peaks for $\mathrm{ZnMn}_{2} \mathrm{O}_{4} \mathrm{aCNF}$ index to the tetragonal spinel $\mathrm{ZnMn}_{2} \mathrm{O}_{4}$ (ICDD\# 01-071-2499).

flowing argon (low $p_{\mathrm{O}_{2}}$ ) reduces $\mathrm{Mn}$ from its initial mixed-valent Mn oxidation state of +3.7 in birnessite $\mathrm{Na}^{+}-\mathrm{MnOx} @ \mathrm{CNF}^{43}$ to the expected +3 Mn oxidation state as verified by XPS (Fig. S1, ESI $\dagger$ ).

Tracking the progress of phase conversion from birnessite $\mathrm{Na}^{+}-\mathrm{MnO} x$ to spinel $\mathrm{ZnMn}_{2} \mathrm{O}_{4}$ with powder X-ray diffraction reveals that exchanging $\mathrm{Na}^{+}$for $\mathrm{Zn}^{2+}$ does not significantly alter the XRD pattern; both $\mathrm{Na}^{+}-$and $\mathrm{Zn}^{2+}$-MnOx@CNF display two broad peaks at 37 and $66^{\circ} 2 \theta$, associated with the disordered birnessite MnOx phase (Fig. 1d). Following thermal treatment, the disordered lamellar $\mathrm{MnO} x$ phase transforms to crystalline spinel that indexes to tetragonal $\mathrm{ZnMn}_{2} \mathrm{O}_{4}$ (Fig. 1d). The average crystallite size is $8 \mathrm{~nm}$, as calculated from wholepattern fitting, confirming that the coating remains nanoscale during transformation from 2D lamellar to 3D spinel.

While no other crystalline phases are observed in the $\mathrm{ZnMn}_{2} \mathrm{O}_{4} @ \mathrm{CNF} \mathrm{XRD}$ pattern, the retention of some minor fraction of disordered MnOx cannot be precluded. Elemental analysis via inductively coupled plasma-atomic emission spectroscopy of $\mathrm{ZnMn}_{2} \mathrm{O}_{4} @ \mathrm{CNF}$ yields a $\mathrm{Mn}: \mathrm{Zn}$ ratio of 2.4, higher than the expected 2.0 for complete conversion. If we assume that all $\mathrm{Zn}$ in the sample exists as $\mathrm{ZnMn}_{2} \mathrm{O}_{4}, 7.7 \%$ of the Mn remains unassociated with the $\mathrm{ZnMn}_{2} \mathrm{O}_{4}$ phase (Table S1 and eqn (S1), ESI $\dagger$ ). Quantitative analysis of the XPS peaks for Mn $2 \mathrm{p}_{3 / 2}$, $\mathrm{Zn} 2 \mathrm{p}_{3 / 2}$, and oxide $\mathrm{O} 1 \mathrm{~s}$ indicates a composition of $\mathrm{ZnMn}_{2.1} \mathrm{O}_{3.8}$, in relative agreement with the expected $\mathrm{ZnMn}_{2} \mathrm{O}_{4}$ stoichiometry (Table 1 and Fig. S1, ESI $\dagger$ ). However, we note that pair-distribution function analysis of the in situ crystal engineering of our disordered $\mathrm{Na}^{+}-\mathrm{MnO}$ @ @CNF to nanocrystalline $\mathrm{LiMn}_{2} \mathrm{O}_{4} @ \mathrm{CNF}$ found that the first plane of $\mathrm{MnO} x$, which forms when $\mathrm{MnO}_{4}{ }^{-}$oxidizes the carbon surface, retains a lamellar morphology that serves as the base of the 3D spinel phase. This foundational plane of $\operatorname{MnO} x$ accounts for the presence of a minor fraction of $\mathrm{Mn}$ remaining in a non-spinel form. ${ }^{44}$ 
Table 1 Composition and structural properties of $\mathrm{ZnMn}_{2} \mathrm{O}_{4} \mathrm{aCNF}$ as a function of electrochemical conditioning in $1 \mathrm{M} \mathrm{ZnSO}_{4}$

\begin{tabular}{|c|c|c|c|c|c|}
\hline Echem cond. & $\mathrm{Mn}: \mathrm{Zn}^{a}$ & $\mathrm{~S}: \mathrm{Zn}^{a}$ & Lattice parameter ${ }^{b} a|b| c$ & Unit cell vol. ${ }^{b}$ & $\mathrm{Zn}_{4}(\mathrm{OH})_{6} \mathrm{SO}_{4}$ precipitate observed? (Method) \\
\hline $\mathrm{OCV} \rightarrow 1.75 \mathrm{~V}^{c}$ & 1.8 & 0.04 & $5.74|5.74| 9.23$ & 304 & No \\
\hline $1.75 \mathrm{~V}^{c}$ & 2.0 & 0.08 & $5.74|5.74| 9.19$ & 303 & No \\
\hline $0.9 \mathrm{~V}^{c}$ & 0.07 & 0.3 & $5.77|.77| 9.23$ & 308 & Macroscale (XRD, SEM) \\
\hline
\end{tabular}

With confirmation of successful phase transformation to spinel, we evaluated the electrochemical performance of $\mathrm{ZnMn}_{2} \mathrm{O}_{4} @ \mathrm{CNF}$ in two-electrode cells versus a $\mathrm{Zn}$ foil anode and using $1 \mathrm{M} \mathrm{ZnSO}_{4}(a q)$ electrolyte. Because as-synthesized $\mathrm{ZnMn}_{2} \mathrm{O}_{4} @ \mathrm{CNF}$ is fully discharged with $\mathrm{Mn}$ in the +3 state, the electrochemical cells were first scanned to voltages positive of open circuit $(\sim 1.5 \mathrm{~V})$. Somewhat surprisingly, the first positive-going voltammetric scan shows no well-defined anodic peak (Fig. 2a), as would be nominally expected for oxidation of $\mathrm{Mn}^{3+}$ sites to $\mathrm{Mn}^{4+}$, accompanied by de-insertion of $\mathrm{Zn}^{2+}$ for charge balance.

To gain insight into this unexpected first-scan behaviour, we performed electrochemical impedance spectroscopy (EIS) of $\mathrm{ZnMn}_{2} \mathrm{O}_{4} @ \mathrm{CNF}$ at $1.75 \mathrm{~V}$ (scanned directly from open circuit) followed by ex situ XPS, SEM/EDS, and XRD characterization of the conditioned electrode. The Nyquist plot reveals a high charge-transfer resistance $\left(R_{\mathrm{CT}}\right)$ of $26 \Omega \mathrm{cm}^{2}$, indicative of significant impediment to multivalent ion extraction from the $\mathrm{ZnMn}_{2} \mathrm{O}_{4}$ domains (Fig. S2, ESI $\dagger$ ). ${ }^{42}$ X-ray photoelectron spectroscopy and EDS corroborate this finding, as the $\mathrm{Zn}$ content after $1.75 \mathrm{~V}$ conditioning is qualitatively similar to the uncycled $\mathrm{ZnMn}_{2} \mathrm{O}_{4} @ \mathrm{CNF}$ (Fig. 2b, c and Fig. S3, ESI $\dagger$ ), revealing that minimal $\mathrm{Zn}^{2+}$ is removed from the spinel lattice during the initial charge. This finding is in agreement with that of Manthiram and co-workers, in which they revealed $\mathrm{Zn}^{2+}$ is not removed from $\mathrm{ZnMn}_{2} \mathrm{O}_{4}$ by $\mathrm{NO}_{2} \mathrm{BF}_{4}$, a chemical mimic for electrochemical Mn oxidation. ${ }^{48}$ Furthermore, no significant changes in lattice parameters or structure are detected by XRD between the initially charged $1.75 \mathrm{~V}$ sample and an uncycled $\mathrm{ZnMn}_{2} \mathrm{O}_{4} @ \mathrm{CNF}$ (Table 1 and Fig. S4, ESI $\dagger$ ).

The ill-defined first-scan voltammetry is consistent with other reports on the initial cycling behaviour of $\mathrm{ZnMn}_{2} \mathrm{O}_{4}{ }^{28,38}$ The absence of $\mathrm{Mn}^{3+/ 4+}$ redox in the first positive scan is in contrast to our previous report with analogous $\mathrm{LiMn}_{2} \mathrm{O}_{4} @ \mathrm{CNF}$, where lattice-sited $\mathrm{Li}^{+}$was easily removed upon initial electrochemical oxidation of the mixed-valent $\mathrm{Mn}^{3+} / \mathrm{Mn}^{4+}$ oxide. ${ }^{43}$ Unlike $\mathrm{LiMn}_{2} \mathrm{O}_{4} @ \mathrm{CNF}$, the voltammetric peaks of $\mathrm{ZnMn}_{2}$ $\mathrm{O}_{4} @ \mathrm{CNF}$ are not well-defined in the first cycle, with only a single reduction peak at $\sim 0.9 \mathrm{~V}$ observed. We attribute this reduction peak to $\mathrm{H}^{+}$insertion, with the supply of protons arising from the mild acidity of $\mathrm{Zn}\left(\mathrm{H}_{2} \mathrm{O}\right)_{6}{ }^{2+}$ in the aqueous Zn-based electrolyte. ${ }^{60}$ The expected redox peaks become welldefined on the second and subsequent cycles, with a single anodic peak paired with two cathodic peaks (Fig. 2a). Such redox peaks are commonly attributed to extraction/insertion of $\mathrm{Zn}^{2+},{ }^{38,49}$ but more recently co-insertion/extraction of $\mathrm{H}^{+}$and $\mathrm{Zn}^{2+}$ into $\mathrm{ZnMn}_{2} \mathrm{O}_{4}$ has been proposed. ${ }^{28}$
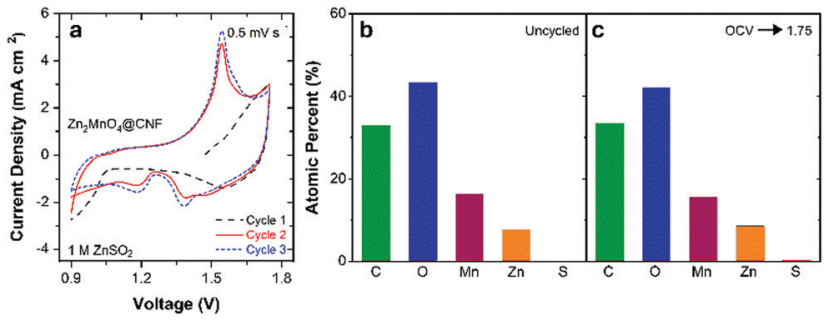

Fig. 2 (a) First three cyclic voltammograms of $\mathrm{ZnMn}_{2} \mathrm{O}_{4} \mathrm{QCNF}$ in $1 \mathrm{M}$ $\mathrm{ZnSO}_{4}$ at $0.5 \mathrm{mV} \mathrm{s}^{-1}$. Atomic percent of each element derived from ex situ $\mathrm{X}$-ray photoelectron spectroscopy of (b) uncycled $\mathrm{ZnMn}_{2} \mathrm{O}_{4} @ \mathrm{CCNF}$ and (c) $\mathrm{ZnMn}_{2} \mathrm{O}_{4} \mathrm{QCNF}$ held at $1.75 \mathrm{~V}$ after linearly scanning directly from OCV in $1 \mathrm{M} \mathrm{ZnSO}_{4}$.

To elucidate the specific $\mathrm{ZnMn}_{2} \mathrm{O}_{4}$ @CNF charge-storage mechanism in aqueous $\mathrm{Zn}^{2+}$-containing electrolytes, we use a multi-pronged approach that includes EIS and ex situ characterization of cells conditioned at pertinent voltages. For data reported in the following sections, all $\mathrm{ZnMn}_{2} \mathrm{O}_{4}$ @CNF-based cells are subjected to: (i) a 10-cycle voltammetric break-in; (ii) a linear scan to the voltage of interest (depicted in Fig. 3a); and (iii) potentiostating at that voltage either for $10 \mathrm{~min}$ prior to EIS data acquisition or for $30 \mathrm{~min}$ for ex situ characterization. Cells are quickly disassembled after voltage conditioning and the $\mathrm{ZnMn}_{2} \mathrm{O}_{4} @ \mathrm{CNF}$ electrode is rinsed copiously with ultrapure water and dried at $50{ }^{\circ} \mathrm{C}$ under flowing $\mathrm{N}_{2}(\mathrm{~g})$.

Electrochemical impedance spectroscopy provides insights into the charge-storage mechanism when performed as a function of applied DC voltage. Nyquist plots from this series of cells reveal significant changes in $R_{\mathrm{CT}}$ during charge (e.g., $1.75 \mathrm{~V}$, "a" in Fig. 3a)
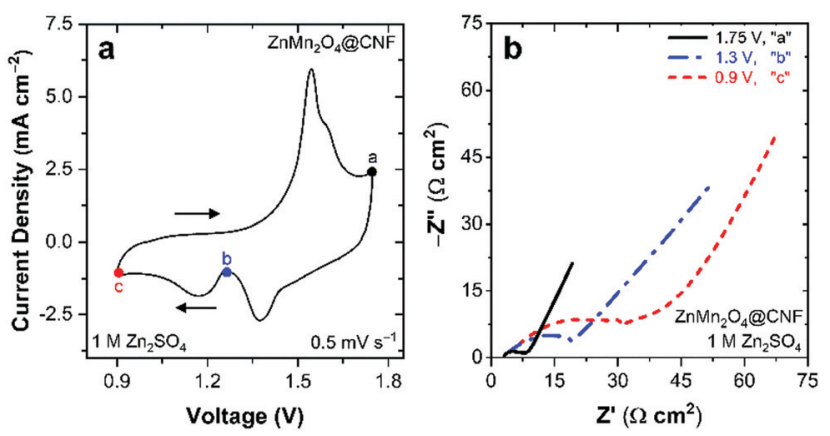

Fig. 3 (a) Cyclic voltammogram showing voltages applied for EIS and subsequent ex situ characterization and (b) Nyquist plot at voltages specified in (a) in $1 \mathrm{M} \mathrm{ZnSO}_{4}$. 
and discharge (e.g., $1.3 \mathrm{~V}$, "b", and $0.9 \mathrm{~V}$, "c", in Fig. 3a). Upon charging at $1.75 \mathrm{~V}$, the $R_{\mathrm{CT}}$ is relatively low at $5 \Omega \mathrm{cm}^{2}$, compared to the $26 \Omega \mathrm{cm}^{2}$ measured after initial charging from open circuit (Fig. S2, ESI $\dagger$ ), revealing that voltammetric break-in enhances performance. Discharging from $1.75 \mathrm{~V}$ to $1.3 \mathrm{~V}$, increases the $R_{\mathrm{CT}} 4 \times$ to $20 \Omega \mathrm{cm}^{2}$ with a further increase to $38 \Omega \mathrm{cm}^{2}$ after discharging at $0.9 \mathrm{~V}$ (Fig. $3 \mathrm{~b}$ ). We previously observed qualitatively similar results for $\mathrm{Na}^{+}-\mathrm{MnO}$ @CNF conditioned in $1 \mathrm{M} \mathrm{ZnSO}_{4},{ }^{36}$ where $R_{\mathrm{CT}}$ increases significantly when fully discharged, arising from the precipitation of electronically insulating $\mathrm{Zn}_{4}(\mathrm{OH})_{6} \mathrm{SO}_{4} \cdot x \mathrm{H}_{2} \mathrm{O}$ at the electrode surface. For $\mathrm{ZnMn}_{2} \mathrm{O}_{4}$ @CNF, the origin of the increase in $\mathrm{R}_{\mathrm{CT}}$ upon discharge is attributed to either $\mathrm{Zn}^{2+}$ transport hindrances and/or precipitation of passivating $\mathrm{Zn}_{4}(\mathrm{OH})_{6} \mathrm{SO}_{4} \cdot x \mathrm{H}_{2} \mathrm{O}$.

We use ex situ X-ray diffraction to monitor the expansion/ contraction of the $\mathrm{ZnMn}_{2} \mathrm{O}_{4}$ lattice that would arise from $\mathrm{Zn}^{2+}$ insertion/extraction and the appearance of $\mathrm{Zn}_{4}(\mathrm{OH})_{6}\left(\mathrm{SO}_{4}\right)$. $x \mathrm{H}_{2} \mathrm{O} .^{27,36,39,50}$ All $\mathrm{ZnMn}_{2} \mathrm{O}_{4} @$ @CNFs harvested from conditioned cells show the main XRD peaks for spinel $\mathrm{ZnMn}_{2} \mathrm{O}_{4}$, indicating that the core crystal structure remains intact through the charge-discharge process (Fig. 4). After charging at $1.75 \mathrm{~V}$, the main $\mathrm{ZnMn}_{2} \mathrm{O}_{4}$ peaks at 29.3, 33.1, and $36.4^{\circ} 2 \theta$ shift to slightly higher $2 \theta$ compared to the uncycled $\mathrm{ZnMn}_{2} \mathrm{O}_{4} @ \mathrm{CNF}$, concomitant with an increase in the $a$ and $b$ lattice parameters and a decrease in the $c$ lattice parameter and unit cell volume (Table 1). Discharging at $1.3 \mathrm{~V}$ does not alter either the main peak positions or corresponding cell parameters (Table 1), revealing that it is unlikely that $\mathrm{Zn}^{2+}$ inserts into the lattice; higher resolution synchrotron experiments are planned in the future to verify this finding.

Upon complete discharge at $0.9 \mathrm{~V}$, additional diffraction peaks appear that index to $\mathrm{Zn}_{4}(\mathrm{OH})_{6}\left(\mathrm{SO}_{4}\right) \cdot x \mathrm{H}_{2} \mathrm{O}$. Because of the overlap of the XRD reflections for $\mathrm{ZnMn}_{2} \mathrm{O}_{4}$ and $\mathrm{Zn}_{4}(\mathrm{OH})_{6}$ $\mathrm{SO}_{4} \cdot x \mathrm{H}_{2} \mathrm{O}$, we are unable to confidently fit XRD data with

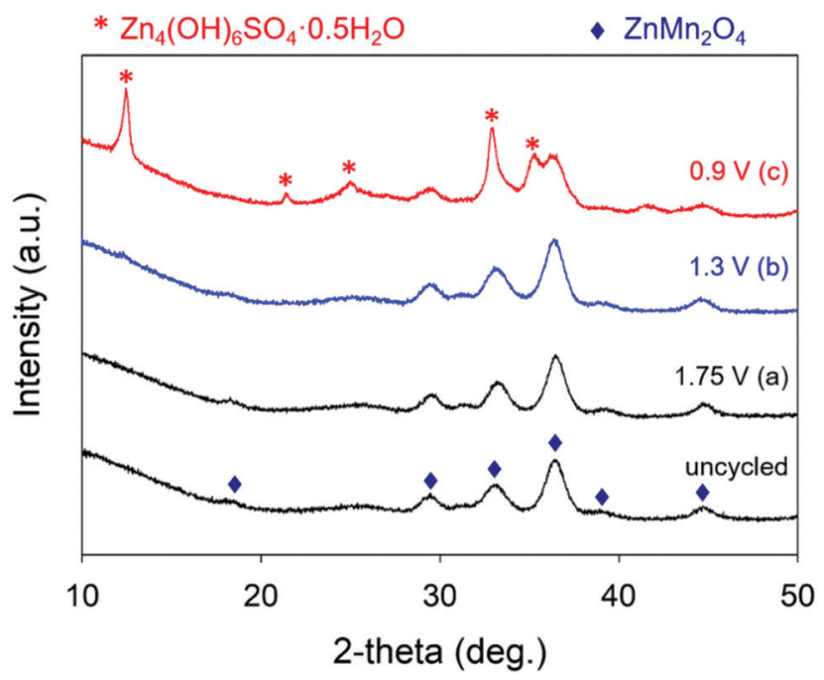

Fig. 4 X-ray powder diffraction patterns of $\mathrm{ZnMn}_{2} \mathrm{O}_{4}$ aCNF electrodes after conditioning at specified voltages in $1 \mathrm{M} \mathrm{ZnSO}_{4}$. The blue diamond denotes peak positions indexed to tetragonal $\mathrm{ZnMn}_{2} \mathrm{O}_{4}$ and the pink asterisk denotes peak positions indexed to $\mathrm{Zn}_{4}(\mathrm{OH})_{6} \mathrm{SO}_{4} \cdot 5 \mathrm{H}_{2} \mathrm{O}$. respect to determining changes in lattice parameters of the $\mathrm{ZnMn}_{2} \mathrm{O}_{4}$ phase, precluding the determination of $\mathrm{Zn}^{2+}$ insertion into the lattice at $0.9 \mathrm{~V}$ (Table 1). The presence of $\mathrm{Zn}_{4}(\mathrm{OH})_{6} \mathrm{SO}_{4} \cdot x \mathrm{H}_{2} \mathrm{O}$ for cells discharged at $0.9 \mathrm{~V}$ is the likely origin of the significant increase in $R_{\mathrm{CT}}$ (Fig. 3b).

Ex situ SEM visualizes morphological changes in $\mathrm{ZnMn}_{2} \mathrm{O}_{4} @ \mathrm{CNF}$ electrodes as a function of cell voltage. Energy-dispersive X-ray spectroscopy provides a means to elucidate the reaction mechanism by monitoring for the appearance of sulfur, as mapped onto the micrographs, in which sulfur serves as an elemental marker for $\mathrm{Zn}_{4}(\mathrm{OH})_{6} \mathrm{SO}_{4} \cdot x \mathrm{H}_{2} \mathrm{O}$. Uncycled $\mathrm{ZnMn}_{2} \mathrm{O}_{4} @ \mathrm{CNF}$ provides the baseline for both morphology and sulfur content.

The exterior surface of the uncycled $\mathrm{ZnMn}_{2} \mathrm{O}_{4} @ \mathrm{CNF}$ is featureless at low magnification and as expected, only adventitious sulfur is detected (Fig. 5a and b). Higher magnification of the exterior surface reveals the through-connected pore structure (Fig. S5, ESI $\dagger$ ), which is also visible in the crosssection (Fig. 5c); minimal sulfur is detected in the interior of the uncycled sample (Fig. 5d).

Charging at $1.75 \mathrm{~V}$ does not yield any significant changes in the morphology of the exterior or interior surfaces (Fig. 5e, g and Fig. S5, ESI $\dagger$ ), but a slight increase in sulfur content is detected (Fig. $5 \mathrm{f}$ and $\mathrm{h}$ ). Upon discharging at $1.3 \mathrm{~V}$, minimal-tono-change in morphology is observed on either the exterior or the interior surfaces (Fig. 5i, k and Fig. S5, ESI $\dagger$ ); however, an increase in sulfur content is visible in the EDS maps (Fig. 5j and l).

A significant change in morphology is observed after discharging at $0.9 \mathrm{~V}$, with large plate-like precipitates visible that extensively cover the exterior surface (Fig. $5 \mathrm{~m}$ and Fig. S5, ESI $\dagger$ ); some of these precipitates protrude into the underlying pore structure (Fig. S5, ESI $\dagger$ ). The cross-sectional micrograph reveals that this layer lies on top of the electrode surface and is $\sim 3 \mu \mathrm{m}$ thick (Fig. 5o). A significant increase in sulfur is detected on

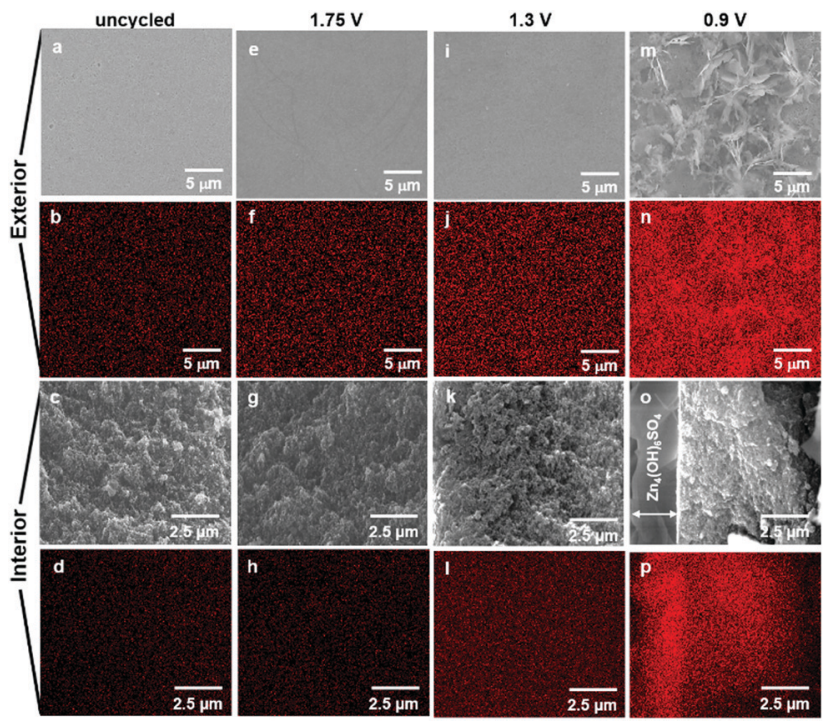

Fig. 5 Scanning electron micrographs and sulfur elemental maps of the exterior surface (top two rows) and interior surface (bottom two rows) of uncycled $\mathrm{ZnMn}_{2} \mathrm{O}_{4} \mathrm{aCNF}(\mathrm{a}-\mathrm{d})$ and after conditioning for $30 \mathrm{~min}$ at $1.75 \mathrm{~V}$ $(\mathrm{e}-\mathrm{h}), 1.3 \mathrm{~V}(\mathrm{i}-\mathrm{l})$, and $0.9 \mathrm{~V}(\mathrm{~m}-\mathrm{p})$ in $1 \mathrm{M} \mathrm{ZnSO}_{4}$ 
both exterior and interior surfaces (Fig. $5 \mathrm{n}$ and p), but with significantly more sulfur concentrated in the $3 \mu \mathrm{m}$-thick exterior layer (Fig. 5p).

The SEM, EDS, and XRD results for $0.9 \mathrm{~V}$-conditioned $\mathrm{ZnMn}_{2} \mathrm{O}_{4} @ \mathrm{CNF}$ substantiate that the micrographically observed exterior layer comprises $\mathrm{Zn}_{4}(\mathrm{OH})_{6} \mathrm{SO}_{4} \cdot x \mathrm{H}_{2} \mathrm{O}$. In addition to confirming the presence of sulfur, the EDS spectra show an increase in $\mathrm{Zn}$ and decrease in Mn (Fig. S6, ESI $\dagger$ ) and the XRD data (Fig. 4) corroborates the presence of crystalline $\mathrm{Zn}_{4}(\mathrm{OH})_{6} \mathrm{SO}_{4} \cdot x \mathrm{H}_{2} \mathrm{O}$. A similar plate-like morphology was also visible on the exterior surface for fully discharged birnessitetype $\mathrm{Na}^{+}-\mathrm{MnO}$ @@CNF electrodes cycled in $1 \mathrm{M} \mathrm{ZnSO}_{4} \cdot{ }^{36}$

The presence of sulfur throughout the interior of the $0.9 \mathrm{~V}$ conditioned electrode (Fig. 5p) coupled with the observation that $\mathrm{Zn}_{4}(\mathrm{OH})_{6} \mathrm{SO}_{4}$ crystallites are oriented orthogonally to the electrode surface, and do not completely occlude the underlying pore structure (Fig. S5, ESI $\dagger$ ), reveals that a large fraction of the electrode volume remains accessible to the electrolyte and available to participate in the charge-storage reaction. The absence of visible $\mathrm{Zn}_{4}(\mathrm{OH})_{6} \mathrm{SO}_{4} \cdot x \mathrm{H}_{2} \mathrm{O}$ precipitates in the interior voids of the $\mathrm{ZnMn}_{2} \mathrm{O}_{4} @ \mathrm{CNF}$ stems from the fact that there is only $10 \%$ of the required $\mathrm{Zn}^{2+}$ for the reaction inside these pores (eqn (S2), ESI $\dagger$ ). ${ }^{36}$

Tracking the atomic ratios (Mn:Zn and S:Zn) by ex situ XPS provides further insight into the charge-storage mechanism. The Mn: $\mathrm{Zn}$ ratio of uncycled $\mathrm{ZnMn}_{2} \mathrm{O}_{4}$ @CNF is 2.1 and after conditioning at $1.75 \mathrm{~V}$ decreases slightly to 2 , revealing a general return to the starting state after voltammetric breakin and charging (Table 1 and Fig. 6a, b). A small amount of sulfur persists after charging at $1.75 \mathrm{~V}$, detectable by both XPS (S:Zn ratio of 0.08) and EDS (Fig. 5f, h and Fig. S6, ESI $\dagger$ ), which we attribute to a patchy $<7 \mathrm{~nm}$-thick $\mathrm{Zn}_{4}(\mathrm{OH})_{6} \mathrm{SO}_{4} \cdot x \mathrm{H}_{2} \mathrm{O}$ layer present at a level below the detection limit of $\mathrm{XRD}$; this insulating coating could also be the source of the contrast differences observed in the corresponding micrograph (Fig. 5e). Discharging at $1.3 \mathrm{~V}$ decreases the $\mathrm{Mn}: \mathrm{Zn}$ ratio to 0.9 , concomitant with an increase in the S:Zn ratio to 0.10 (Table 1 and Fig. 6c). The binding energy of the $S 2 p_{3 / 2}$ peak is $168.8 \mathrm{eV}$, consistent with sulfate, indicating either that $\mathrm{SO}_{4}{ }^{2-}$ associates at edge sites or that nanoscale $\mathrm{Zn}_{4}(\mathrm{OH})_{6} \mathrm{SO}_{4} \cdot x \mathrm{H}_{2} \mathrm{O}$ is present below the detection limits of XRD. The Mn:Zn ratio decreases by over an order of magnitude to 0.07 upon discharge at $0.9 \mathrm{~V}$ (Table 1 and Fig. 6d), attributed to screening of the underlying $\mathrm{ZnMn}_{2} \mathrm{O}_{4}$ by the $3 \mu \mathrm{m}$-thick $\mathrm{Zn}_{4}(\mathrm{OH})_{6}\left(\mathrm{SO}_{4}\right) \cdot x \mathrm{H}_{2} \mathrm{O}$ overlayer (Fig. 5o). By measuring a $\mathrm{Zn}$ - and S-rich surface ( $\mathrm{S}: \mathrm{Zn}$ ratio $=0.3$; Fig. 6d), the XPS data are consistent with the presence of $\mathrm{Zn}_{4}(\mathrm{OH})_{6} \mathrm{SO}_{4} \cdot x \mathrm{H}_{2} \mathrm{O}$.

Although $\mathrm{ZnMn}_{2} \mathrm{O}_{4}$ contains specific insertion sites for $\mathrm{Zn}^{2+}$, our data confirm that the dominant charge-storage mechanism for $\mathrm{ZnMn}_{2} \mathrm{O}_{4} @ \mathrm{CNF}$ is $\mathrm{H}^{+}$insertion/de-insertion with subsequent precipitation/dissolution of $\mathrm{Zn}_{4}(\mathrm{OH})_{6}\left(\mathrm{SO}_{4}\right) \cdot x \mathrm{H}_{2} \mathrm{O}$, similar to that observed on our birnessite-like $\mathrm{Na}^{+}-\mathrm{MnO}$ @ @ CNF. ${ }^{36}$ This same reaction mechanism has been proposed for $\mathrm{VO}_{2},{ }^{51,52}$ $\mathrm{V}_{3} \mathrm{O}_{7} \cdot \mathrm{H}_{2} \mathrm{O},{ }^{53,54} \mathrm{~V}_{2} \mathrm{O}_{5},{ }^{55} \mathrm{NaV}_{3} \mathrm{O}_{8},{ }^{56} \mathrm{~V}_{10} \mathrm{O}_{24} \cdot 12 \mathrm{H}_{2} \mathrm{O},{ }^{57}$ and $\mathrm{Co}_{3} \mathrm{O}_{4}{ }^{58}$ cathode materials, revealing that $\mathrm{pH}$ changes upon $\mathrm{H}^{+}$insertion/de-insertion is a general charge-storage mechanism for oxide-based materials in aqueous $\mathrm{ZnSO}_{4}$ electrolytes, as recently suggested by Kundu and co-workers. ${ }^{53}$

Circumventing this general precipitation/dissolution process would be advantageous from a performance standpoint (e.g., long-term cycling and rate), but swapping $\mathrm{NO}_{3}{ }^{-}$for $\mathrm{SO}_{4}{ }^{2-}$ is not feasible, as the former is too oxidizing for the $\mathrm{Zn}$ anode. Buffering the $\mathrm{SO}_{4}{ }^{2-}$ electrolyte, however, may be an effective strategy to suppress the precipitation of the $\mathrm{Zn}_{4}(\mathrm{OH})_{6} \mathrm{SO}_{4} \cdot x \mathrm{H}_{2} \mathrm{O}$ salt and is the focus of future experiments.

A charge-storage mechanism that involves precipitation/ dissolution of $\mathrm{Zn}_{4}(\mathrm{OH})_{6}\left(\mathrm{SO}_{4}\right) \cdot x \mathrm{H}_{2} \mathrm{O}$ on the surface of the $\mathrm{ZnMn}_{2} \mathrm{O}_{4} @ \mathrm{CNF}$ electrode influences both the capacity and rate of $\mathrm{Zn}$-ion cells; and as such, 3D electrode-architecture designs play a role in energy-storage performance. Cyclic voltammometric examination of $\mathrm{ZnMn}_{2} \mathrm{O}_{4} @ \mathrm{CNF}$ as a function of scan rate reveals that $\mathrm{ZnMn}_{2} \mathrm{O}_{4}$-based redox peaks are discernible at scan rates as high as $10 \mathrm{mV} \mathrm{s}^{-1}$ (Fig. 7a). This impressive rate performance, for a nominal battery material, is due to sufficient counter-ion compensation from both an adequate volume of electrolyte within the pores and to rapid transport of ions to the $\mathrm{ZnMn}_{2} \mathrm{O}_{4}$ domains via the through-connected pore structure of the underlying CNF. A 3D design-enabled performance we have demonstrated with CNFs modified with other MnOx polymorphs. ${ }^{59}$

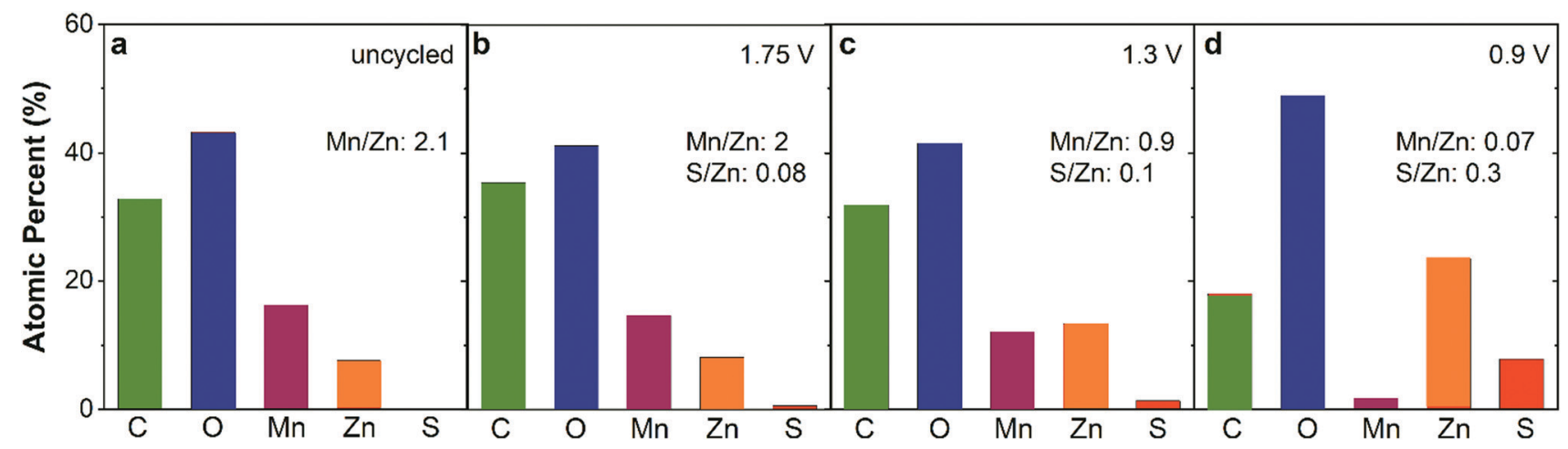

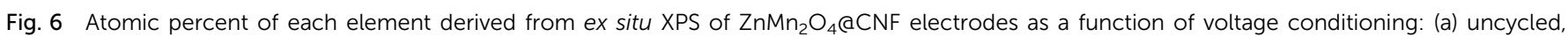
(b) $1.75 \mathrm{~V}$, (c) $1.3 \mathrm{~V}$, and (d) $0.9 \mathrm{~V}$ in $1 \mathrm{M} \mathrm{ZnSO}_{4}$ 

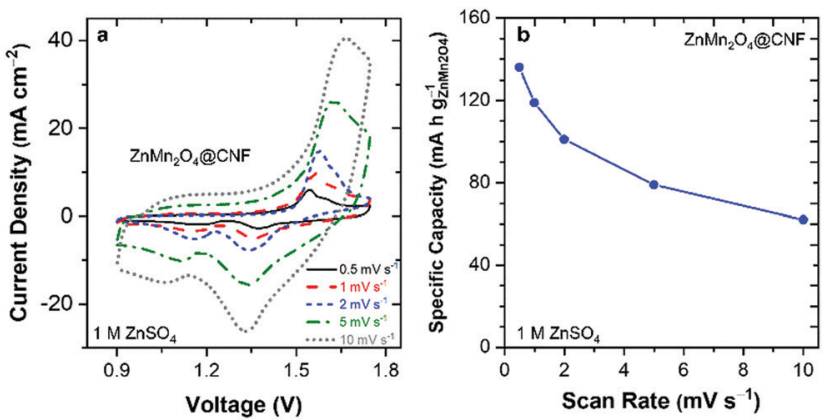

Fig. 7 (a) Cyclic voltammograms and (b) specific capacity of $\mathrm{ZnMn}_{2} \mathrm{O}_{4} @ \mathrm{CCNF}$ in $1 \mathrm{M} \mathrm{ZnSO}_{4}$ as a function of scan rate.

A specific capacity of $119 \mathrm{~mA} \mathrm{~h} \mathrm{~g} \mathrm{ZnMn2O}^{-1}$ is delivered at $1 \mathrm{mV} \mathrm{s}^{-1}$ (Fig. 7b), on par with the 1-electron theoretical capacity of $\mathrm{ZnMn}_{2} \mathrm{O}_{4}\left(116 \mathrm{~mA} \mathrm{~h} \mathrm{~g}^{-1}\right)$, further confirming that the charge-storage mechanism is $\mathrm{H}^{+}$insertion $/ \mathrm{Zn}_{4}(\mathrm{OH})_{6} \mathrm{SO}_{4}$ precipitation. As the scan rate increases to $10 \mathrm{mV} \mathrm{s}^{-1}$, the capacity decreases to $62 \mathrm{~mA} \mathrm{~h} \mathrm{~g}^{-1}$ (Fig. 7b). The realization of theoretical specific capacity is a consequence of the $3 \mathrm{D}$ multifunctional electrode architecture (Fig. S7, ESI $\dagger$ ). The $20 \mathrm{~nm}$ thick $\mathrm{ZnMn}_{2} \mathrm{O}_{4}$ domains are well-wired to the underlying carbon current collector, as it is generated from the precursor $\mathrm{MnO} x$ phase that is deposited via $\mathrm{MnO}_{4}{ }^{-1}$ redox deposition. In this deposition, the carbon in the nanofoam serves as a sacrificial reductant, and thus the first few layers of the MnOx are embedded into the carbon current collector. ${ }^{43,46,47}$ The through-connected pore volume/structure of the 3D multifunctional electrode ensures an adequate supply and rapid transport of ions to the $\mathrm{ZnMn}_{2} \mathrm{O}_{4}$ domains, ${ }^{59}$ supporting rapid chargedischarge at nominally high rates $\left(1 \mathrm{mV} \mathrm{s}^{-1}=28 \mathrm{~min}\right.$ charge/ discharge) for a battery material. This 1-electron high-capacity at high rate is in agreement with our previous results for both crystalline spinel $\mathrm{LiMn}_{2} \mathrm{O}_{4} @ \mathrm{CNF}$ and $\mathrm{Na}^{+}$-birnessite-type $\mathrm{MnOx}$ @ $\mathrm{CNF}$, where these electrodes deliver full theoretical capacity (148 $\mathrm{mA} \mathrm{h} \mathrm{g}^{-1}$ at $2 \mathrm{mV} \mathrm{s}^{-1}$ and $308 \mathrm{~mA} \mathrm{~h} \mathrm{~g}^{-1}$ at $1 \mathrm{C}$, respectively)



Fig. 8 Capacity versus cycle number for $\mathrm{ZnMn}_{2} \mathrm{O}_{4} @ \mathrm{aCNF}$ in $1 \mathrm{M} \mathrm{ZnSO}_{4}$ at a $1 \mathrm{C}$ rate. when cycled in $\mathrm{Li}^{+}$- and $\mathrm{Zn}^{2+}$-containing aqueous electrolytes, respectively. ${ }^{35,43}$

Long-term electrochemical stability is a key requirement for $\mathrm{MnO} x$-based active materials used in aqueous $\mathrm{Zn}$-ion cells. We cycle $\mathrm{ZnMn}_{2} \mathrm{O}_{4} @ \mathrm{CNF}$ in two-terminal cells with a $\mathrm{Zn}$-foil anode and $1 \mathrm{M} \mathrm{ZnSO}_{4}$ electrolyte at $1 \mathrm{C}\left(136 \mathrm{~mA} \mathrm{~h} \mathrm{gnnn}_{\mathrm{ZnM}^{-1}}{ }^{-1}\right.$ for 400 cycles (7 weeks). Capacity decays significantly over the first 200 cycles and plateaus from cycle 200 to 400, leading to a $50 \%$ decrease in total capacity (Fig. 8).

The mildly acidic nature of $1 \mathrm{M} \mathrm{ZnSO}_{4}(\mathrm{aq})$ is known to promote reductive dissolution of $\mathrm{MnO} x$ as $\mathrm{Mn}^{3+}$ disproportionates to generate soluble $\mathrm{Mn}^{2+}$, which could be the source of the capacity fade. To assess this hypothesis, we soaked $\mathrm{ZnMn}_{2} \mathrm{O}_{4} @ \mathrm{CNF}$ in $1 \mathrm{M}$ $\mathrm{ZnSO}_{4}$ for 13 days and upon addition of potassium periodate to a portion of the solution, the electrolyte changed from colorless to magenta, indicating the presence of soluble $\mathrm{Mn}^{2+}$ species (Fig. S8, $\mathrm{ESI} \dagger$ ), confirming the disproportionation reaction resulting from the mild acidity of $1 \mathrm{M} \mathrm{ZnSO}_{4}$. Gravimetric analysis of the $\mathrm{ZnMn}_{2} \mathrm{O}_{4} @ \mathrm{CNF}$ after soaking in $1 \mathrm{M} \mathrm{ZnSO}_{4}$, revealed a $6 \mathrm{wt} \%$ loss, leaving $35 \mathrm{wt} \% \mathrm{ZnMn}_{2} \mathrm{O}_{4}$ for charge-storage.

This long-term stability problem has been previously addressed by adding $\mathrm{Mn}^{2+}$ (e.g., $0.010-0.05 \mathrm{M} \mathrm{MnSO}_{4}$ ) to the electrolyte to drive the equilibrium back toward $\mathrm{Mn}^{3+/ 4+}$ oxide, resulting in extended cycle life. ${ }^{38}$ We do not obtain such improvements when using $0.05 \mathrm{M} \mathrm{MnSO}_{4}+1 \mathrm{M} \mathrm{ZnSO}_{4}$ in our cycling studies. For our particular electrode structure, we calculate that if $10 \%$ of the nanofoam-supported $\mathrm{ZnMn}_{2} \mathrm{O}_{4}$ were to dissolve, the $\mathrm{Mn}^{2+}$ concentration would reach $0.7 \mathrm{M}$ inside the pores (eqn (S3), ESI $\dagger$ ). This degree of dissolution likely represents an extreme condition, but reveals that $0.05 \mathrm{M} \mathrm{Mn}^{2+}$ is insufficient at suppressing the disproportionation reaction in this porous $\mathrm{CNF}$ architecture. In on-going experiments, we are exploring other strategies, including buffering the electrolyte, ${ }^{30,60}$ as well as methods to form nanoscale protective coatings at the oxide surface, as previously achieved using bicarbonate electrolyte additives at $\mathrm{LiMn}_{2} \mathrm{O}_{4}$ @CNF. ${ }^{43}$

\section{Conclusions}

Our ability to crystal engineer $2 \mathrm{D}$ lamellar birnessite-like $\mathrm{Na}^{+}-\mathrm{MnO} x$ inside high surface-area CNF is extended to generate nanocrystalline $\mathrm{ZnMn}_{2} \mathrm{O}_{4} @ \mathrm{CNF}$. We show that despite specific lattice sites for $\mathrm{Zn}^{2+}$ insertion into the spinel, the dominant charge-storage mechanism of $\mathrm{ZnMn}_{2} \mathrm{O}_{4} @ \mathrm{CNF}$ in $1 \mathrm{M} \mathrm{ZnSO}_{4}$ remains $\mathrm{H}^{+}$insertion/ de-insertion coupled with precipitation/dissolution of $\mathrm{Zn}_{4}(\mathrm{OH})_{6}$ $\mathrm{SO}_{4} \cdot x \mathrm{H}_{2} \mathrm{O}$. A $50 \%$ decrease in capacity is observed over 400 cycles when cycled at $1 \mathrm{C}$, which is attributed to dissolution of $\mathrm{ZnMn}_{2} \mathrm{O}_{4}$, the bulk of which resides in the CNF interior, via disproportionation of electrogenerated $\mathrm{Mn}^{3+}$ to $\mathrm{Mn}^{4+}$ and soluble $\mathrm{Mn}^{2+}$.

\section{Experimental}

Chemicals and materials

Resorcinol (Sigma Aldrich, 99\%), formaldehyde (Sigma Aldrich, 37 wt $\%$ in $\mathrm{H}_{2} \mathrm{O}, 10-15 \%$ methanol stabilizer), sodium carbonate 
(Aldrich Chemical Company, Inc., $99.5+\%$ ), $\mathrm{Na}_{2} \mathrm{SO}_{4}$ (Sigma Aldrich, $\geq 99.0 \%$ ), $\mathrm{NaMnO}_{4} \cdot \mathrm{H}_{2} \mathrm{O}$ (Sigma Aldrich, $\geq 97 \%$ ) and $\mathrm{ZnSO}_{4}$ (Sigma Aldrich, $\geq 99.0 \%$ ) were used as received. Carbon fiber papers (Lydall Technimat), cellulose acetate filters $(1.2 \mu \mathrm{m}$ pores, SterliTech Corporation), and $0.25 \mathrm{~mm} \mathrm{Zn}$ foil (Alfa Aesar, 99.98\% metal basis) were used as described.

\section{$\mathrm{ZnMn}_{2} \mathrm{O}_{4} @ \mathrm{CNF}$ synthesis}

One-ply 40/500 carbon nanofoam papers (CNF) were fabricated using a previously reported protocol. ${ }^{61}$ Briefly, the $40 / 500$ resorcinol-formaldehyde (RF) sol was prepared by mixing $10 \mathrm{~g}$ resorcinol $+14.74 \mathrm{~g}$ formaldehyde $+0.0177 \mathrm{~g}$ sodium carbonate $+13.9 \mathrm{~g}$ water and stirring on a magnetic stir plate set at $250 \mathrm{rpm}$ for $30 \mathrm{~min}$, followed by a $2.5 \mathrm{~h}$ resting period. Carbon fiber papers $\left(2.5 \times 4.5 \mathrm{~cm}^{2}\right)$ were exposed to an air-ice RF plasma (Harrick PlasmaFlo PDC-FMG) for 45 min to introduce oxygen functionalities on the carbon fiber surfaces. The CFPs were then vacuum-infiltrated with the RF sol to generate RF-CFPs and placed between two glass slides with each glass slide edge secured with a mini binder clip. The glass slide assembly was then sealed in duct tape. The RF-CFPs were placed in an aluminum foil pouch with $\sim 2 \mathrm{~mL}$ of water and allowed to cure under ambient conditions for $20 \mathrm{~h}$, then placed in a pressure cooker (Nesco 3-in-1, Target) for $9.5 \mathrm{~h}$ at "slow cook" ( 88-94 $\left.{ }^{\circ} \mathrm{C}\right)$ and then at "warm" until removed. The RF-CFPs were removed from the glass slides, soaked in nanopure water and acetone, each for $1 \mathrm{~h}$, and dried under ambient conditions. Pyrolysis of the RF-CFPs was performed in a tube furnace (Thermo Scientific Lindberg Blue $\mathrm{M}$ ) under flowing argon by ramping to $1000{ }^{\circ} \mathrm{C}$ at a $1{ }^{\circ} \mathrm{C} \mathrm{min}^{-1}$ and held at $1000{ }^{\circ} \mathrm{C}$ for $2 \mathrm{~h}$ to generate carbon nanofoam papers (CNFs).

Manganese oxide (birnessite-like $\mathrm{Na}^{+}-\mathrm{MnO} x$ ) was electrolessly deposited onto the "one-ply 40/500" CNF by soaking under vacuum in $0.1 \mathrm{M} \mathrm{Na}_{2} \mathrm{SO}_{4}$ for $20 \mathrm{~h}$ and then in $0.1 \mathrm{M}$ $\mathrm{NaMnO}_{4} \cdot \mathrm{H}_{2} \mathrm{O}+0.1 \mathrm{M} \mathrm{Na}_{2} \mathrm{SO}_{4}$ for $20 \mathrm{~h}$, generating $\mathrm{Na}^{+}-$ MnOx@CNF. ${ }^{46}$ The $\mathrm{Na}^{+}-\mathrm{MnO}$ @@CNF were removed from the $\mathrm{NaMnO}_{4}$ solution, thoroughly rinsed with nanopure water, vacuum infiltrated with nanopure water and soaked under vacuum for $1 \mathrm{~h}$; the rinse/soak process was repeated a total of three times. The $\mathrm{Na}^{+}-\mathrm{MnO}$ @ @ CNF were dried at $50{ }^{\circ} \mathrm{C}$ under flowing $\mathrm{N}_{2}(\mathrm{~g})$ for $20 \mathrm{~h}$.

To generate $\mathrm{ZnMn}_{2} \mathrm{O}_{4} @ \mathrm{CNF}$, the $\mathrm{Na}^{+}-\mathrm{MnO}$ @ @CNFs were vacuum infiltrated with $1.0 \mathrm{M} \mathrm{ZnSO}_{4}$ solution and soaked under vacuum for $24 \mathrm{~h}$, removed from the $1 \mathrm{M} \mathrm{ZnSO}_{4}$ solution, rinsed copiously with nanopure water, and soaked in nanopure water under vacuum for $1 \mathrm{~h}$, with the nanopure water rinse/ soak step repeated two more times. The $\mathrm{Zn}^{2+}$-MnOx@CNFs were dried at $50{ }^{\circ} \mathrm{C}$ under flowing $\mathrm{N}_{2}(\mathrm{~g})$ for $12 \mathrm{~h}$. Next, the $\mathrm{Zn}^{2+}$-MnOx@CNF papers were placed in a tube furnace under flowing argon, ramped to $300{ }^{\circ} \mathrm{C}$ at a rate of $2{ }^{\circ} \mathrm{C} \mathrm{min}^{-1}$, held at $300{ }^{\circ} \mathrm{C}$ for $4 \mathrm{~h}$, and then cooled to ambient temperature before removing from the furnace.

\section{Elemental analysis}

A $\mathrm{ZnMn}_{2} \mathrm{O}_{4}$ @CNF sample was analyzed to quantitatively determine $\mathrm{Mn}, \mathrm{Na}$, and $\mathrm{Zn}$ content (sent to Galbraith Laboratories, Inc.).
Prior to analysis by inductively coupled plasma-atomic emission spectroscopy, the samples were dried under vacuum.

\section{Electrochemical characterization}

Prior to electrochemical tests, the $\mathrm{ZnMn}_{2} \mathrm{O}_{4}$ @CNF electrode was vacuum-infiltrated with $1 \mathrm{M} \mathrm{ZnSO}_{4}$ for $4 \mathrm{~h}$. Two-electrode $\mathrm{Zn}$-ion Swagelok cells were fabricated with a $\mathrm{ZnMn}_{2} \mathrm{O}_{4} @ \mathrm{CNF}$ cathode $\left(1 / 2^{\prime \prime}\right.$ diameter circle), a cellulose acetate filter wetted with $1 \mathrm{M} \mathrm{ZnSO}_{4}$ as the separator, and a $0.25 \mathrm{~mm}$-thick $\mathrm{Zn}$ foil as the anode. A Gamry REF 600 potentiostat was used to collect cyclic voltammetry, linear sweep voltammetry, chronoamperometry, and AC electrochemical impedance spectroscopy data. Cyclic voltammetry was carried out from $0.9 \mathrm{~V}$ to $1.75 \mathrm{~V}$ at scan rates of $0.5,1,2,5$, and $10 \mathrm{mV} \mathrm{s}^{-1}$. Ex situ and EIS data on $\mathrm{ZnMn}_{2} \mathrm{O}_{4} @ \mathrm{CNF}$ samples were generated by first doing a 10-cycle voltammetric breakin from 1.75 to $0.9 \mathrm{~V}$ to $1.75 \mathrm{~V}$ at $2 \mathrm{mV} \mathrm{s}^{-1}$, followed by linear-scan voltammetry at $0.5 \mathrm{mV} \mathrm{s}^{-1}$ to a specified voltage $(1.75 \mathrm{~V}, 1.3 \mathrm{~V}$, or $0.9 \mathrm{~V}$ ) and holding at that voltage for either $30 \mathrm{~min}$ for ex situ characterization samples or $10 \mathrm{~min}$ for EIS. After electrochemical conditioning, the cell voltage was terminated, the $\mathrm{ZnMn}_{2} \mathrm{O}_{4} @ \mathrm{CNF}$ was immediately removed, rinsed well with nanopure water, and dried under flowing $\mathrm{N}_{2}(\mathrm{~g})$ for $12 \mathrm{~h}$ prior to analysis by XPS, XRD, and SEM/EDS.

\section{Long-term cycling}

Two-terminal Zn-ion cells with $\mathrm{ZnMn}_{2} \mathrm{O}_{4} @ \mathrm{CNF}$ cathodes assembled as described above were galvanostatially cycled at \left. 1C (136 ${\mathrm{mAh} \mathrm{g}_{\mathrm{ZnMn}_{2} \mathrm{O}_{4}}}^{-1}\right)$ on an Arbin battery cycler.

\section{Scanning electron microscopy}

Exterior surface samples were cut with clean scissors and secured to aluminum stubs with conductive carbon tape (Ted Pella). Cross-sectional samples were prepared by immersing uncycled and conditioned $\mathrm{ZnMn}_{2} \mathrm{O}_{4} @ \mathrm{CNF}$ samples in liquid nitrogen for $1 \mathrm{~min}$, fractured with a new razor blade, and secured to a $45 / 90^{\circ}$ aluminum stub with conductive carbon tape. Carbon paint was used to make an electrical connection between the exposed surface and the SEM stub, especially critical for imaging samples with electrically insulating $\mathrm{Zn}_{4}(\mathrm{OH})_{6}\left(\mathrm{SO}_{4}\right) \cdot x \mathrm{H}_{2} \mathrm{O}$ precipitates. All samples were imaged with a Leo Supra 55 SEM at $20 \mathrm{keV}$ equipped with an Oxford Instruments Aztec energy-dispersive X-ray detector.

\section{X-ray photoelectron spectroscopy}

Elemental analyses of the surface of the electrodes were performed using XPS (Thermo Scientific K-Alpha X-ray) equipped with a monochromatic $\mathrm{Al} \mathrm{K} \alpha$ source $(1486.68 \mathrm{eV})$ and a $400 \mu \mathrm{m}$ elliptical spot size. High-resolution spectra over the C 1s, O 1s, Mn 2p, S 2p, and Zn 2p regions were obtained. The instrument was operated using a low-energy electron flood gun; the resulting spectra were not peak-shifted prior to quantitative analysis. Ratios of $\mathrm{Mn}: \mathrm{Zn}$ and $\mathrm{S}: \mathrm{Zn}$ were tracked to monitor the degree of precipitated film formation of $\mathrm{Zn}_{4}(\mathrm{OH})_{6}\left(\mathrm{SO}_{4}\right) \cdot x \mathrm{H}_{2} \mathrm{O}$. The spectra were analyzed with Avantage (version 5.35). 


\section{X-ray diffraction}

$\mathrm{X}$-ray diffraction patterns were collected for MnOx@CNF and $\mathrm{ZnMn}_{2} \mathrm{O}_{4} @ \mathrm{CNF}$ series using a $3 \mathrm{~kW}$ Rigaku Smartlab X-ray diffractometer operating with a $\mathrm{Cu} \mathrm{K} \alpha(\lambda=1.5406 \AA)$ radiation source in continuous mode. The samples were aligned with the incident X-rays by sandwiching each sample between a glass slide and the Rigaku reference sample holder. The average crystallite sizes of selected samples were calculated using peak broadening determined from whole pattern fitting in the Rigaku PDXL analysis software. The reference structure for the pattern fitting was $\mathrm{ZnMn}_{2} \mathrm{O}_{4}$ (ICDD\# 01-071-2499).

\section{Conflicts of interest}

The authors have no conflicts to declare.

\section{Acknowledgements}

This work was supported by the U.S. Office of Naval Research.

\section{Notes and references}

1 Y. Chabre and J. Pannetier, Prog. Solid State Chem., 1995, 23, 1-130.

2 M. M. Thackeray, Prog. Solid State Chem., 1997, 25, 1-71.

3 D. Bélanger, T. Brousse and J. W. Long, ECS Interface Spring, 2008, 17, 49-52.

4 C. J. Xu, F. Y. Kang, B. H. Li and H. D. Du, J. Mater. Res., 2010, 25, 1421-1432.

5 M. Huang, F. Li, F. Dong, Y. X. Zhang and L. L. Zhang, J. Mater. Chem. A, 2015, 3, 21380-21423.

6 Q. Z. Zhang, D. Zhang, Z. C. Miao, X. L. Zhang and S. L. Chou, Small, 2018, 14, 1702883-1702897.

7 B. Tang, L. Shan, S. Liang and J. Zhou, Energy Environ. Sci., 2019, 12, 3288-3304.

8 X. Zeng, J. Hao, Z. Wang, J. Mao and Z. Guo, Energy Storage Mater., 2019, 20, 410-437.

9 J. Ming, J. Guo, C. Xia, W. Wang and H. N. Alshareef, Mater. Sci. Eng., R, 2019, 135, 58-84.

10 M. Song, H. Tan, D. Chao and H. J. Fan, Adv. Funct. Mater., 2018, 41, 1802564.

11 L. E. Blanc, D. Kundu and L. F. Nazar, Joule, 2020, 4, 771-799.

12 Y.-P. Deng, R. Liang, G. Jiang, Y. Jiang, A. Yu and Z. Chen, ACS Energy Lett., 2020, 5, 1665-1675.

13 Y. Wu, J. Fee, Z. Tobin, A. Shirazi-Amin, P. Kerns, S. Dissanayake, A. Mirich and S. L. Suib, ACS Appl. Energy Mater., 2020, 3, 1627-1633.

14 A. Dhiman and D. G. Ivey, Batteries Supercaps, 2020, 3, 293-305.

15 B. Yong, D. Ma, Y. Wang, H. Mi, C. He and P. Zhang, Adv. Energy Mater., 2020, 2002354.

16 J. Lee, J. B. Ju, W. I. Cho, B. W. Cho and S. H. Oh, Electrochim. Acta, 2013, 112, 138-143.
17 M. H. Alfaruqi, V. Mathew, J. Gim, S. Kim, J. Song, J. P. Baboo, S. H. Choi and J. Kim, Chem. Mater., 2015, 27, 3609-3620.

18 M. H. Alfaruqi, J. Gim, S. Kim, J. Song, J. Jo, S. Kim, V. Mathew and J. Kim, J. Power Sources, 2015, 288, 320-327.

19 H. Qin, Z. Yang, L. Chen, X. Chen and L. Wang, J. Mater. Chem. A, 2018, 6, 23757-23765.

20 Y. Cheng, L. Luo, L. Zhong, J. Chen, B. Li, W. Wang, S. X. Mao, C. Wang, V. L. Sprenkle, G. Li and J. Liu, ACS Appl. Mater. Interfaces, 2016, 8, 13673-13677.

21 H. Liang, Z. Cao, F. Ming, W. Zhang, D. H. Anjum, Y. Cui, L. Cavallo and H. N. Alshareef, Nano Lett., 2019, 19, 3199-3206.

22 G. Li, Z. Yang, Y. Jiang, C. Jin, W. Huang, X. Ding and Y. Huang, Nano Energy, 2016, 25, 211-217.

23 P. Hu, T. Zhua, X. Wang, X. Zhou, X. Wei, X. Yao, W. Luo, C. Shi, K. A. Owusu, L. Zhou and L. Mai, Nano Energy, 2019, 58, 492-498.

24 J. S. Ko, P. P. Paul, G. Wan, N. Seitzman, R. H. DeBlock, B. S. Dunn, M. F. Toney and J. N. Weker, Chem. Mater., 2020, 32, 3028-3035.

25 H. Pan, Y. Shao, P. Yan, Y. Cheng, K. S. Han, Z. Nie, C. Wang, J. Yang, X. Li, P. Bhattacharya, K. T. Mueller and J. Liu, Nat. Energy, 2016, 1, 16039.

26 B. Lee, H. R. Seo, H. R. Lee, C. S. Yoon, J. H. Kim, K. Y. Chung, B. W. Cho and S. H. Oh, ChemsusChem, 2016, 9, 2948-2956.

27 Y. Wu, K. Zhang, S. Chen, Y. Liu, Y. Tao, X. Zhang, Y. Ding, T. Hayat, A. M. Abusorrah and S. Dai, ACS Appl. Energy Mater., 2020, 3, 319-327.

28 Z. Yao, D. Cai, Z. Cui, Q. Wang and H. Zhan, Ceram. Int., 2020, 46, 11237-11245.

29 D. L. Chao, W. H. Zhou, C. Ye, Q. H. Zhang, Y. G. Chen, L. Gu, K. Davey and S. Z. Qiao, Angew. Chem., Int. Ed., 2019, 58, 7823-7828.

30 C. F. Bischoff, O. S. Fitz, J. Burns, M. Bauer, H. Gentischer, K. P. Birke, H.-M. Henning and D. Biro, J. Electrochem. Soc., 2020, 167, 020545-020553.

31 D. Wu, L. M. Housel, S. J. Kim, N. Sadique, C. D. Quilty, L. Wu, R. Tappero, S. L. Nicholas, S. Ehrlich, Y. Zhu, A. C. Marschilok, E. S. Takeuchi, D. C. Bock and K. J. Takeuchi, Energy Environ. Sci., 2020, 13, 4322-4333.

32 T. Zhang, Y. Tang, G. Fang, C. Zhang, H. Zhang, X. Guo, X. Cao, J. Zhou, A. Pan and S. Liang, Adv. Funct. Mater., 2020, 3, 2002711.

33 L. Li, T. K. A. Hoang, J. Zhi, M. Han, S. Li and P. Chen, ACS Appl. Mater. Interfaces, 2020, 12, 12834-12846.

34 W. Sun, F. Wang, S. Hou, C. Yang, X. Fan, Z. Ma, T. Gao, F. Han, R. Hu, M. Zhu and C. Wang, J. Am. Chem. Soc., 2017, 139, 9775-9778.

35 J. S. Ko, M. B. Sassin, J. F. Parker, D. R. Rolison and J. W. Long, Sustainable Energy Fuels, 2018, 2, 626-636.

36 J. S. Ko, M. D. Donakowski, M. B. Sassin, J. F. Parker, D. R. Rolison and J. W. Long, MRS Commun., 2019, 9, 99-106.

37 N. Zhang, F. Cheng, Y. Liu, Q. Zhao, K. Lei, C. Chen, X. Liu and J. Chen, J. Am. Chem. Soc., 2016, 138, 12894-12901. 
38 X. Wu, Y. Xiang, Q. Peng, X. Wu, Y. Li, F. Tang, R. Song, Z. Liu, Z. He and X. Wu, J. Mater. Chem. A, 2017, 5, 17990-17997.

39 L. Chen, Z. Yang, H. Qin, X. Zeng and J. Meng, J. Power Sources, 2019, 425, 162-169.

40 J.-W. Lee, S.-D. Seo and D.-W. Kim, J. Alloys Compd., 2019, 800, 478-482.

41 L. Chen, Z. Yang, H. Qin, X. Zeng, J. Meng and H. Chen, Electrochim. Acta, 2019, 317, 155-163.

42 H. Zhang, J. Wan, Q. Liu, W. He, Z. Lai, X. Zhang, M. Yu, Y. Tong and X. Lu, Energy Storage Mater., 2019, 21, 154-161.

43 M. B. Sassin, S. G. Greenbaum, P. E. Stallworth, A. N. Mansour, B. P. Hahn, K. A. Pettigrew, D. R. Rolison and J. W. Long, J. Mater. Chem. A, 2013, 1, 2431-2440.

44 M. D. Donakowski, J. M. Wallace, M. B. Sassin, K. W. Chapman, J. F. Parker, J. W. Long and D. R. Rolison, CrystEngComm, 2016, 18, 6035-6048.

45 J. S. Ko, M. B. Sassin, D. R. Rolison and J. W. Long, Electrochim. Acta, 2018, 275, 225-235.

46 A. E. Fischer, K. A. Pettigrew, D. R. Rolison, R. M. Stroud and J. W. Long, Nano Lett., 2007, 7, 281-286.

47 M. B. Sassin, C. N. Chervin, D. R. Rolison and J. W. Long, Acc. Chem. Res., 2013, 46, 1062-1074.

48 J. C. Knight, S. Therese and A. Manthiram, J. Mater. Chem. A, 2015, 3, 21077-21082.

49 S. Yang, M. Zhang, X. Wu, X. Wu, F. Zeng, Y. Li, S. Duan, D. Fan, Y. Yang and X. Wu, J. Electroanal. Chem., 2019, 832, 69-74.
50 V. Soundharrajan, B. Sambandam, S. Kim, S. Islam, J. Jo, S. Kim, V. Mathew, Y.-K. Sun and J. Kim, Energy Storage Mater., 2020, 28, 407-417.

51 Z. Li, S. Ganapathy, Y. Xu, Z. Zhou, M. Sarilar and M. Wagemaker, Adv. Energy Mater., 2019, 9, 1900237-1900246.

52 Q. Pang, H. Zhao, R. Lian, Q. Fu, Y. Wei, A. Sarapulova, J. Sun, C. Wang, G. Chen and H. Ehrenberg, J. Mater. Chem. A, 2020, 8, 9567-9578.

53 D. Kundu, S. H. Vajargah, L. Wan, B. Adams, D. Prendergast and L. F. Nazar, Energy Environ. Sci., 2018, 11, 881-892.

54 P. Oberholzer, E. Tervoort, A. Bouzid, A. Pasquarello and D. Kundu, ACS Appl. Mater. Interfaces, 2019, 11, 674-682.

55 Y. Dong, M. Jia, Y. Wang, J. Xu, Y. Liu, L. Jiao and N. Zhang, ACS Appl. Energy Mater., 2020, 3, 11183-11192.

56 X. Shan, S. W. Kim, A. M. M. Abeykoon, G. Kwon, D. Olds and X. Teng, ACS Appl. Mater. Interfaces, 2020, 12, 54627-54636.

57 W. Liu, L. Dong, B. Jiang, Y. Huang, X. Wang, C. Xu, Z. Kang, J. Mou and F. Kang, Electrochim. Acta, 2019, 320, 134565.

58 L. Ma, S. Chen, H. Li, Z. Ruan, Z. Tang, Z. Liu, Z. Wang, Y. Huang, Z. Pei, J. A. Zapiena and C. Zhi, Energy Environ. Sci., 2018, 11, 2521-2530.

59 M. B. Sassin, C. P. Hoag, B. T. Willis, N. W. Kucko, D. R. Rolison and J. W. Long, Nanoscale, 2013, 5, 1649-1657.

60 M. Mateos, N. Makivic, Y.-S. Kim, B. Limoges and V. Balland, Adv. Energy Mater., 2020, 10, 2000332.

61 J. C. Lytle, J. M. Wallace, M. B. Sassin, A. J. Barrow, J. W. Long, J. L. Dysart, C. H. Renninger, M. P. Saunders, N. L. Brandell and D. R. Rolison, Energy Environ. Sci., 2011, 4, 1913-1925. 